Historic, Archive Document

Do not assume content reflects current scientific knowledge, policies, or practices. 
Twenty-two range weeds are discussed in this report prepared 1956 for the Range Reseeding Equipment Committee as follows:

Page

Scrub oak

Chol la cacti

Tansy ragwort

Leafy spurge

Whitetop

Cluster tarweed

St. John's Wort

Water-hemlock

3
5
7
9
11
13
15
17

Page

Fringed sagewort

Bitterweed

Prickly pear

Post and blackjack oak

Saw palmetto

Gallberry

Western false-hellebore
19 Russian knapweed

20 Canada thistle

22 Wild iris

24 Willows

Foxtail barley

26 Greasewood

28 Broom snakeweed

Page

A report similar to this that covered sixteen range weeds was written in 1955. These two reports now present chemical control recommendations for a total of 38 different range weeds.

Membership of this 1956 comittee with agency affiliation and location is as follows:

Karl G, Parker, Extension Range Specialist, Montana State College Bozeman, Montana

W. C. Robocker, Agronomist, Weed Investigations Section, Field Crops Research Branch, Agricultural Research Service, Reno, Nevada

S. I. Cuskelly, Range Conservationist, U. S. Forest Service, Ogden, Utah

Fred H. Tshirley, Weed Investigations Section, Agricultural Research Service, Santa Rita Research Center, Tucson, Arizona

Vernon A. Young, Head 'of Department of Range and Forestry, Agricultural and Mechanical College of Texas, College Station, Texas

Lowell K. Halls, Range Conservationist, Southeastern Forest Experiment Station, U. S. Forest Service, Tifton, Georgia

Donald N. Hyder, Range Conservationist, Agricultural Research Service, Squaw Butte-Harney Experiment Station, Burns, Oregon

Myrvin E. Noble, Bureau of Land Management, U. S. Department of Interior, Washington 25, D.C.

Donald R. Cornelius, Range Conservationist (Research), Forage and

Range Section, Agricultural Research Service, P.0. Box 245, Berkeley 1, California, Chairman of the Committee.

No claims are made that all of these plants are always undesirable on the range. Under certain conditions some of the plants may serve a useful purpose as we shall point out in a few of the sections. Under

Report of Subcommittee on Chemical Control of Range Weeds, Range Reseeding Equipment Committee Meeting,

Great Falls, Montana, January 27-28, 1957

Mimeographed by U. S. Forest Service, 630 Sansome Street, San Francisco, Calif. 
such exceptional circumstances, control of the plants would not be justified nor desired. On the other hand, a few of the plants are more important as weeds on cropland than on rangeland. However, we cannot permit our rangeland to become a reservoir for perpetuating such weeds. The judgement of the rancher or range manager will need to be exercised first in deciding upon what plants are to be controlled on his land. If weedy plants are determined to be undesirable on a particular range area and information useful in their control is given in these reports to the advantage of the rancher or range manager, then the mission of this committee is being accomplished.

Chemical control procedures are reported here as determined from published literature, first hand experience, and personal correspondence. In making a review of this kind some difficulty is always encountered in evaluating all results on an equal basis. Certain variation in interpretation of results may occur depending upon the situation and the individual. We attempted to give unprejudiced treatment and as complete as time and facilities: would permit. With certain range weeds the information is sketchy because a lack of research on particular species and problems may exist at the present time. In such cases we point out the need for more experimentation and testing. In all cases with the remarkable advances being made on weed control problems, we should expect new developments to appear that will increase effectiveness and efficiency of control for range weeds.

We have attempted to use chemical terminology, designations, and abbreviations as published in Weeds 4.(3): 280-282, July 1956. A few examples most widely used are the following:

2,4-D for 2,4-dichlorophenoxyacetic acid 2, 4,5-T for 2, 4, 5-trichlorophenoxyacetic acid 2-(2,4-DP) for 2-(2, 4-dichlorophenoxy) proprionic acid

2-(2,4,5-TP) or silvex for 2-(2,4,5-trichlorophenoxy) proprionic acid dalapon for 2,2-Dichloroproprionic acid ahg for acid equivalent per 100 gallons gpa for gallons per acre ppm for parts per.million gpm for gallons per minute T.C.A. for trichloroacetic acid

Esters of 2,4-D and 2, 4,5-T are frequently designated high volatile or light esters when referring to the butyl, isopropyl, ethyl, methyl, or amyl esters. The low volatile or heavy esters are terms commonly used when referring to butoxyethanol, propylene glycol butyl ether (abbreviated $\mathrm{PGBE}$ ), polyethylene glycol mono, isooctyl, and tetrahydrofurfuryl esters of $2,4-D$ or $2,4,5-T$. 
SCRUB OAK (Quercus turbinella Greene and/or Q. dumosa Nutt.)

\section{Distribution and Description}

The taxonomy of the scrub oak or shrub live oak is not consistent at the present time. Kearney and Peebles (2) separate Q. turbinella as a distinct entity in the Arizona chaparral. Jepson (1), on the contrary, lists Q. turbinella as a variety of Q. dumosa, which is found in the California chaparral. For practical purposes, there is little distinction between the two plents other than their geographic distribution. Both are dominant in the chaparral vegetation type which is found primarily in Arizona and California. The plant is a shrub or small tree up to 10 feet high forming extremely dense thickets with other chaparral species. Leaves are toothed and covered with a more or less whitened bloom.

Best Herbicides

Only a limited amount of chemical control research has been done on the mature stands of this species and it has been uniformly unsuccessful. Tschirley (7) reported on an aerial spray of chaparral in June 1953. The percentage defoliation on oak ranged from 0 to 40 percent for different treatments but no plant kjll was recorded. More detailed work has been done on oak sprouts following fire. Leonard $(3,4,5)$ reports that a brush-killer ( $1: 1$ Mixture of 2, L-D and 2, L,5-T) in the chaparral type is recommended, because some species in this vegetation complex are more susceptible to 2,4-D than 2,4,5-T. He mentions also, that 2-(2,4-dichlorophenoxy) propicnic acid and 2-(2,4,5-trichlorophenoxy) propionic acid looked promising in the California chaparral. Schmutz and Turner (6) sprayed oak sprouts with a number of different chemicals at various intervals following fire. They found that the low volatile ester of $2-(2,3,5-T P)$ was the best herbicide tested followed by the low volatile esters of $2,4,5-T$ and $2-(2,4-D P)$.

Rate, Volume, and Carrier

Apparently, high concentrations and igh volumes are necessary to effect control even on the sprouts of oak. Leonard, in his work in California. used spray solutions as high as $4 \mathrm{lbs}$, active ingredient in 40 gallons of corrier. Schmutz and Turner used a concentration of 10,000 p.p.m. (3.2 lbs/LO gal) in their work. This was all hand-spray work, so the rates and volumes per acre cannot be accurately determined. The most efficient carrier, generally, is an emulsion of diesel oil and water. Leonard used a 1 percent diesel oil in water, while Schmutz and Turner used a 1:10 S/V Sovaspray 100.water ratio. S/V Sovaspray 100 is a non-toxic oil. A high-volume apolication was made in all cases.

\section{Time of Application}

The best time for treating sprouts is not exactly known. Leonard reported treatments on sprouts 2 years following a burn. Schmutz and Turner made 6 treatments, the first 3 months after the fire and the last 12 montns after the fire. Best results were obtained beginning 6 months after the June burn, at which time foliage was well developed and the winter rains had begun. After this date there was little difference in kill for dates of application with the best chemicals. 
General Considerations

Chemical treatment by itself on mature plants is not considered feasible at this time. Usually there is only a partial defoliation of the plants and they refoliate very rapidly.. The most promising practice seems to be the chemical treatment of sprouts following fire.

\section{References}

(1) Jepson, W. 'I.

1925. Manual of flowering plants of California. Sathergate Book Shop, Berkeley.

(2) Kearney, T. H. and R. H. Peebles.

1951. Arizona flora. Univ. of Calif. Press, Berkeley and Los Angeles.

(3) Leonard, O.A.

1954. Recent results on the chemical control of woody plants on California rangelands. Res.Prog. Rept. Western Weed Control Conference, pp. "44-45.

(4)

1956. Control of woody plants in combination with other methods. Proc. 15th Western Weed Control Conference, pp. 93-98.

(5) , and W. A. Harvey

1956. Chemical control of woody plants in California. Calif. Agr. Exp. Sta. Bul. $755,50 \mathrm{pp}$.

(6) Schmutz, E. M., and $R_{0} M_{0}$. Turner

1956. Unpublished data, Dept. of Agron. \& Range Management, Univ. Ariz。Tucson.

(7) Tschirley, $\mathrm{F}$. H.

1954. Chaparral - still a problem. Progressive-Agr. in Ariz. $6(1): 8$. 


\section{CHOLIA CACTI (Opuntia spp。) \\ Distribution and Description}

The major distribution of cholla cacti is centered in desert and semidesert areas, with Arizona having the highest population in North America. Other than Arizona, Nev Mexico is the only state which considers cholla cacti a problem on rangelands. Chulla cacti belong to the sub-genus Cylindropuntia. Ihey are characterized by having cylindrical joints, inconspicuous glochids, and sheathed spines. In growth form they vary from low growing, spreading plants to tall, arborescent forms.

\section{Best Herbicides}

There are nowerbicides presentiy available that will control cholla cacti economically on extensive areaso. Currently, the only place for chemical control of cholla lies in spot treatments of small localized infestations. In this respect, a number of herbicides can be used to advantage. I'schirley (5) has data showing that the low volatile ester of $2-(2,4,5 \cdots \mathrm{TP}) \sqrt{2}-(2,4,5-i \mathrm{ichlorophenoxy})$ propionic acidT and $2,4,5-\mathrm{T}$ $(2,4,-5$-trichlorophenoxyacetic acid) will give adequate control. Roach and GI endening $(3,4)$ report further that TCA (trichloroacetic acid) and $\operatorname{DNBP}(4,6$-dinitro ortho secondiary butyl.phenol) are effective for spot treatments.

\section{Rate, Volume, and Carrier}

High concentrations must be used. Ten to twelve thousand p.p.m. (6 $\left.\frac{\mathrm{l}}{2}-8 \mathrm{lbs} \mathrm{ahg}\right)$ in diesel oil are recommended for $2 \rightarrow(2,4,5-\mathrm{TP})$ and 2,4,5-T, while 15,000 p.p.m. (10 lbs/100 gal) are recommended for DNBP. One-half to three-fourths pound of TCA per gallon of water also gives adequate control. With the exception of TCA, diesel oil was the best carrier for thz other herbicides mentioned. In all cases, a high volume was necessary. Plants were individually sprayed to the point of drip. Ischirley (5) also reports that 4 pounds acid equivalent per acre in a total. volume of 40 geilons of a diesel oil: water emulsion gave only a l? percent ki.l. It is apparent, therefore, that both high concentrations and high volumes are necessary to achieve effective control of cholla cactio

\section{Time of Appication}

JuIy and Augusis are the best months for treatments with 2- $2,4,5-\mathrm{TP})$ and 2,4,5-T. DNBP and TCA car be effectively used over a wider range of season, but treatments should not, be made during extremely dry seasons (3).

\section{General Considerations}

It is doubtiul that chemicai control alone will ever be a practical method of controlling cholla. Eren if a complete kill were obtained, there would be a large number of dead joints lying on the ground which would prevent proper atilization of forage species by livestock. Since 
approximately 40 percent of a cholla infestation can be killed (2) by the use of fire, it seems that fire may become a valuable tool for the control of cholla.

\section{References}

1. Benson, Iyman. 1940. Cacti of arizona. Univ, Ariz. Bul. Biol. Sci. Bul. \#5, $134 \mathrm{pp}$.

2. Reynolds, H. G., and J. W. Bohning. 1956. Some effects of fire on a semidesert grassiand range. Ecol. (In press).

3. Roach, Mack E. 1955. Cholla cacti--its spread and control. Ariz. Stockman 18-19, 24-25.

4. and G. E. Glendening. 1953. Chemical tests on cactus and burroweed. Res. Prog. Rept. Western Weed Control Conf. p. 27.

5. Tschirley, F. H. 1956. Unpublished data.

Fred H. Tschirley 


\section{TANSY RAGWORT (Senecio jacobaea L.) \\ Distribution and Description}

Tansy ragwort was introduced to America from Europe. It was first reported from the northeastern United States and the province of Quebec, but has since been reported from the island of Vancouver and from Brition Columbia to northem California. There is no published record of its occurrence in the north central states, indicating that this may have been a double introduction, one taking place in the east and the other in the west. Leaves are 2 to 8 inches long and finely divided. The yellow flower heads are one-half to three-fourths of an inch wide.

Best Herbicides

Tansy ragwort can be controlled if it is treated in the proper stage. Hughes (4) reports an 80 percent kill using the amine of 2,4-D. Furtick and Chilcote (2) report that the butoxyethanol ester of 2, L-D was the most effective chemical tested. Amine triazole was not effective at any stage of growth.

\section{Rate, Volume, and Carrier}

Furtick and Chilcote (2) reported a rate of 2 pounds acid equivalent per 100 gallons of carrier was adequate for effective control. Hughes had good success with 1.5 pounds acid equivalent of the amine in 40 gallons of water per acre. Little work has been done with carriers for the control of this species.

Time of Application

Control was effective only when treatments were made at the rosette or bolt stages. Later treatments were not effective with any chemical.

General Considerations

This species is apparently spreading quite rapidly and is becoming a cause for concern, especially in the Pacific Northwest. It invades pastures, wet places, and cultivated ground, particularly. In addition to its competitive characteristics it is also poisonous. This weed has a potentially greater geographic distribution and we will no doubt be hearing much more about it in future years.

\section{References}

1. Anonymous. 1955. Control of weeds on ranges and pastures. Proc. 8th Annual Canadian Weed Control Conference.

2. Furtick, W. R., and D. O. Chilcote. 1955. A comparison of various herbicides on tansy ragwort when applied at rosette, bolt, and bloom stages. Res. Prog. Rept. WiwCC pp. 8-9.

3. The use of amino triazole on tansy ragwort in the rosette, bolt, and bloom stages. Res. Prog. Rept. WWCC pp. 9. 
4. Hughes, E. C. 1955. Effect of herbicides on ragwort (Senecio jacobaea) Reș. Rept. Nat. Weed Comm. (Western Section).

5. Renney, A. J. 1955. Tansy ragwort (Senecio jacobaea I.) in British Columbia. Res. Rept. Nat. Weed Comm. (Western Section) pp. 125.

6. List of weeds in the 11 western states compiled by A. N. Stewart Curator, Oregon State College.

Fred H. Tschirley 


\section{LEAFY SPURGE（Euphorbia esula L.)}

Leafy spurge is a noxious field weed of the Euphorbiaceae family. It is a herbaceous perennial that spreads vigorously from rootstocks. The stems are erect with densely leafy branches. Although it is known to have been introduced from Europe, little is known of the extent of its distribution on this continent. It is particularly bothersome in the Northern Rocky Mountain and North Central States and Canada.

\section{Chemicals}

Isopropyl ester of 2,4-D alone and supplemented with ammate gave good kills in central Montana as did isopropyl ester of 2, L-D along with alternate tillage and competitive crops of wheat, barley and wheatgrasses.

Polybor, polybor-chlorate, borascu and sodium chlorate also give good kills of leafy spurge when properly applied.

The soil fumigant prochlor when applied at adequate rates and treated at proper spacing intervals resulted in complete eradication of leafy spurge. Amizol has also shown promise for control of leafy spurge.

\section{Rate, Volume and Carrier}

Four and six pounds of isopropyl ester of 2,4-D in 20 gallons of water applied nine times during a four-year period, resulted in 98 percent kill of leafy spurge. Complete kills have been obtained with four pounds of isopropyl ester of 2, 4-D and 100 pounds of ammate per acre followed by application of four pounds of 2,4-D the following spring.

Although complete eradication was not obtained, 99 percent control resulted from four years' rotation of 2,4-D at the rate of $3 / 4$ pound per acre with tillage and seeding 90 pounds of winter wheat per acre.

Polybor chlorate at the rate of 15 pounds per square rod gave 100 percent kill by the end of the third year. Polybor at the rate of 30 pounds per square rod gave 99 percent kill by the end of the third year.

Borascu at 30 pounds per square rod resulted in 98 percent kill by the end of the third year and sodium chlorate at six pounds per square rod resulted in 87 percent kill after three years. 2,4-D ester dust at 15 pounds acid equivalent per acre gave 98 percent kill. Atlacide at 3.5 pounds per 100 -square feet resulted in 97 percent kill.

Four pounds of Amizol in 100 gallons of water per acre is recommended for solid stands of leafy spurge. 


\section{Time of Application}

Amizol should be applied when leafy spurge begins to bud and flower but before any seeo pods rorm. Ireatments of 15 pounds of acid equivalent of $2,4-D$ should be mäe in hud or early bloom stage. Applications of 2;4-D were made with good results, in central Montana in May, when leafy spurge was in the but stage.

\section{Genera Considerations}

Intensive cultivation carried on over a two or three year period, or alternated with cropping, will erroicate leafy. spurge. Continuance of cultivation mu be for a perjod suficiently long (at least two years) to kil ali roots of ail plants. Where cultivating and cropping are alternated, a longer period it required. Regularity of cultivations from early spring to irearip ai 14 dey intervals, with perhaps a lengthening of periods as the pin weaken arture the first year, are recommended.

\section{References}

1. Baker, Tuwrence 0, Control of Jeafy Sourge (Euphorbia esula) with Herbicides, Hes. Pog. Repont, Western Weed Control Conference, 1954, pp. 6.7 .

2. Beatty, $R_{0} H_{n}$, Prooress Report on 3aAmino 1,2,2,..Triazole (Amizol), Proceedings Californit. Weed Conference, 1956, page 62.

3. Bohmont, Dale Wo Control of Russian Inapieed, Leafy Spurge, Canada Thistie and Whiteio with Growth Regulatirg Compounds, Res. Prog. Report Western Weed Controi Confarence, 1952, page 13.

4. Davis, Ray J., Filora of Idaho, 1952 , page $4,60$.

5. Kraj.1, James I., Ghenice?s and Competitive Crops for the Control of Leafy Spurge ir Ceritial Montana. Miontana Agr. Erp. Sta. Bull. $510,1955, \mathrm{pp} .2-15$.

6. Kratochvil, D. E, I. M. Stahler and I. A. Derscheid, Chemical Control of Weeds in Scuth Dalsota, Sousin Dekota Agr. Exp. Sta. Bull. 69,1951 , page 6. 


\section{WHITETOP (Cardaria draba, Desv॰) \\ Description and Distribution}

Whitetop is a noxious weed of cultivated ground and roadsides that is rapidly spreading onto overgrazed rangelands. Because of its dense growth and ability to spread underground, as well as by seeds, it has become estab]ished on considerable lands in the Intermountain region and California. It was introduced from Europe and is now widespread in America.

\section{Chemicals}

Whitetop is sensitive to 2,4-D. Amine types have given higher kills where cropping or cultivation programs were involved. However, where no cropping or cultivation was involved, the ester types gave the best results. 2, 4-D is superior to 2, 4, 5-T for control of whitetop.

Sodium chlorate has brought fair results but under average conditions about six pounds per square rod are required.

Although it has sometimes failed on adobe clay soils, carbon bisulfide has proven to be reasonably satisfactory for control of whitetop. Amino triazole looks good in coastal areas.

$$
\text { Rate, Volume and Carrier }
$$

Three applications in one season followed by a similar number the second season of one pound of 2,L-D acid per acre have resulted, in good kills in South Dakota. In California, four pounds per acre of low-volatile ester or amine forms of 2,4-D, followed by two pounds per acre, after the first two treatments, gave good kills. These materials should be applied in a sufficient amount of water to thoroughly wet the plants. Ninety-five percent (95\%) control can be expected after three years of three applications of 2,4-D each growing season.

Under average conditions, about six pounds of sodium chlorate per square rod gives fair results.

Rates of 4 to 8 pounds of amino triazole per acre, applied in water as a drenching spray, shows promise of giving good kills.

\section{Time of Application}

Applications of 2,4-D are most effective at the bud stage of growth and the late fall rosette stage of growth.

\section{General Considerations}

2,4-D when used alone is less effective in controlling whitetop than when it is combined with cropping and cultural practices. 
In the drier regions, where only one application can be made during the growing season, the dormacy of whitetop extends the eradication period for several years.

Soil sterilization to eradicate whitetop on noncropped lands has been quite unsuccessful in many cases because it is quite tolerant to sodium chlorate under some soil conditions, particularly alkaline soils.

\section{References}

1. Bohmont, Dale W., Control of Russian Knapweed, Leafy Spurge, Canada Thistle and Whitetop with Growth Regulating Compounds, Res. Prog. Report, Western Weed Control Conference, 1952, pp. 12-13.

2. Davis, Ray J., Flora of Idaho, 1952, pp. 335.

3. Hodgson, Jesse M., Controlling Whitetop (Cardaria draba) with 2,4-D, Res. Prog. Report, Western Weed Control Conference, 1952, p. 11.

4. Control of Whitetop (Cardaria draba) by Combined Chemical Cropping and Tillage Methods, Res. Prog. Report, Western Weed Control Conference, 1952, pp. 11-12.

5. Progress Report of Weed Investigations at the Meridian Weed Experiment Station, Idaho Noxious Weed Assoc. Annual Meeting, 1950, pp. 14-16.

6. Koehler, James W., Whitetop. Proceedings California Weed Conference, 19.56, pp. 122-123.

7. Kratochvile, D. E., L. M. Stahler and L. A. Derscheid, Chemical Control of Weeds in South Dakota, So. Dakota Ag. Expt. Sta. Bull. $69 ; 1951$, pp. 5-6.

8. Krall, J. L., A General Report on Four Years of Research on the Use of Herbicides for the Control of Whitetop (Cardaria spp.), Res. Prog. Report, Western Weed Control Conference, 1952, p. 10. 


\section{CLUSTER TARTEED (Madia glomerata Hook.)}

Description and Distribution

Cluster tarweed is a herbaceous annual of the Compositae family that attains a height of 4 to 20 inches. It is glandular, hairy and strongly tarmscented. In the Intermountain area it most cormonly occurs in openings at elevations from 6 to 10 thousand feet. It is a heavy. invader of overgrazed mcuntain ranges that frequently have the potential of being some of the best. Tarweed seed germinates early in the spring (occasionally under sncwbants) and nakes vi.gorous growth, maturing in late summer. It is distributed from Saskatchewan to Colorado and California and introduced eastwisd.

\section{Chemicals}

Tarweed may be control?ed by spraying with 2,4-D at the rate of $1 / 2$ to one pound acid equivalent per acre cither as the amine salt or ester. The Pacific Northwest Forest and Range Experiment Station reports good kills with one pound of sodium salt of $2,4-D$ per acre.

$$
\text { Race, Volurne and Carrier }
$$

Of the various methods of application of 2,4-D to tarweed infestations, only ground spray rigs have been tried. These trials indicate that $1 / 2$ to one pound of $2,4-1$ in up to 30 gallons of water per acre may be recommended, depending on the volume necessary to wet all parts of the plants.

\section{Time of Application}

Spraying should be done before the tarweed plants reach the fourleaf stage of growih. Reclucel kills resulted when plants were sprayed in the 6-to 10 leaf stage of growin because of larger plants intercepting the spray.

\section{General Considerations}

Soil cultivation arter foliage ieaves develop, but before seed begins to form, will also kill tarreed.

Tarweed appears to produce a substance which is toxic or inhibitory to both the growth and seed germination of other plants.

If needed, adapted grasses shoula be planted immediately following tarweed kills to take advantage of the remaining snow-melt moisture as well as that of sumer storins.

\section{References}

1. Davis, Ray J., Tlora of Idaho: 1952, pp。768-769

2. Parker, Roberi $E_{\text {, }}$ The Inhibitory Effects of Nadia Glomerata upon Seed Germination and Plant Growth, Thesis, University of Utah, 1950, pp. $55^{\circ}$. 
3. Plumer, Perry A., A. C. Hull, Jr., George Stewart, and Joseph H. Robertson, Seeding Rangelands in Utah, Nevada, Southern Idaho and Western Wyoming, U.S. Dept. of Agri. Handbook No. 71, 1955, pp. $24-25$

4. Stevenson, E. "W, Reseeding Tarweed Infested Ranges, U. S. Forest Service, Pacific Northwest Expt. Sta. Research Note 68, 1950 page 6.

5. U. S. Forest Service Intermountain Forest and Range Expt. Sta., Annual Report, Artificial Revegetation 1952, pp. 27-29

S. L. Cuskelly 
ST. JOHN'S WORT, GOATWEED, OR KLAMATH WEHD (Hypericum perforatum L.)

\section{Description and Occurrence}

St. John's Wort is one of the most aggressive, noxious, introduced range plant invaders. By 1951 it had invaded more than 2 million acres in the western United States. Infestations probably extend over twice that many acres now. Its most objectionable feature is its ability to crowd out valuable range forage plants once it obtains a foothold through disturbance or misuse of range.

St. John's Wort is a perennial plant. It grows in rather dense patches and spreads both by seeds and root stocks. The plants grow to a height of 1.5 to 25 inohes and have yellow, five-petaled flowers. The flowers are about three..fourths of an inch in diameter. The petals have numerous black dots around the edges, the more or less oblong shaped leaves are arranged in pairs along the stem and have small pinhole-like glands that appear to be transparent when held up to the light.

This plant is a native of Western Europe and has spread practically around the world.

\section{Chemicals}

The three chemicals which are most commonly used for control are commercial borax, proprietary forms of borax (Borascu), and 2, 4-D. Borax preparations are used on small out-lying infestations, while the 2, 4-D is used on the 3arger infestations and scattered stands.

$$
\text { Rate, Volume and Carrier }
$$

From 4 to 8 pounds of borax per square rod, have been used, but the heavier application is the most satisfactory. This treatment is usually applied in the spring. The chomical is broadcast on the soil or drilled in.

Treated stands chould be marked and follow up checks made to insure that all plants are $k 1$. 3 ed.

2.4-D is applied at the rate of 2 to 3 pounds or more of acid equivalent per acre apolied in earlit summer, or when the plants are in the bud stage, Either water or oil is used as a carrier and applied at a minimum rate or 10 gall ons of water or 3 gallons of oil per acre.

The cost of chemical treatments limits their use. However, they can be justified as a means of preventing the spread from sporadic infestations.

General Considerations

Range in good or excellent condition is less likely to be invaded by St. John's Wort? 
Biological control of St. John's Wort has been attempted through the introduction of beetles which feed specifically on St. John's Wort plants. Beetles have given highly successful controll on extensive stands in Caijfornia and later in other states where they were subsequently introduced.

Root borers are currently being tried in some sites in the West but provide less successful control than the beetles.

\section{References}

Baker, I. O., et al, 1956. Weed control in Montana on lawns and in crops on range. Montana State College Agri. Expt. Sta. C-210.

Evanko, Anthony B., 1953. The test of borax control of goatweed. Northerm Rocky Mt. Forest \& Range Expt. Sta. USFS Mimeo. 134.

Harris, Grant A., 1951. St. John's Wort on western ranges. Northern Rocky Mt. Forest \& Range Expt. Sta. USFS. Sta. Paper No. 26.

Huffaker, C. B., 1953. Quantitative studies of the biological control of St. John's Wort (Klamath Weed) in California. Proceedings. Seventh Pacific Science Congress, Vol. 4, p. 303.

Karl G. Parker 


\section{WATER-HEMLOCK (Cicuta spp.) \\ Description and Occurrence}

Water-hemlock is a native perennial which reproduces both by seeds and lleshy roots. It grows in marshy ground and along live streams where there is an accumulation of rich loamy soils.

It occurs abundantly in northern and eastern United States and in adjacent Canada, extending southwestward.

The stems are erect, branching, stout, hollow and jointed. Leaflets are distinquished by the peculiar manner in which the veins in the leaflets run to the notches on the edge of the leaflet. It has a characteristic appearance of the parsley family.

\section{Chemicals}

The ester form of $2,4-D$ is the most practical chemical for use in controlling water-hemlock. Soil sterilants often are impractical because of the excessive moisture of the sites in which this plant normally grows.

\section{Rate of Application, Volume and Carrier}

2,4-D applied in the early growth stage and up to the early bud stage has produced excellent kills. It is considered to be very sensitive to 2,4-D in these stages. Water is used as the carrier and applied at approximately 10 gallons per acre, or more, where the infestation is very dense and growth is luxuriant. 2, 4-D should be applied at the rate of 2 pounds per acre.

\section{General Ccnsiderations}

Where it is a problem, water-hemlock is one of the more deadly poisonous plants.

Caution should be taken to remove livestock from sprayed areas. 2,4-D sprays tend to increase the palatability of water-hemlock to livestock. Plants normally ignored by cattle grazing in the pasture are more readily grazed following spraying and may cause serious losses.

\section{References}

Baker, I. O., et al, 1956. Weed control in Montana. Montana State College Agr。 Expt。Sta. Cir。210

Bohmont, Dale W., 1951. Chemical control of poisonous range plants. Fifth annual proceedings Nebraska weed conference.

Hodgson, Jesse M。1956。 Personal conference. USDA. ARS. Bozeman, Montana. 
Muenscher, W. C., 1955. Weeds, MacMillan Co. Second Edition, p. 223. Western Weed Control Conference Research Progress Report, 1952, p.35. 
FRIVGED SAGEWORT (Artemisia frigida Willd.)

\section{Description and Occurrence}

This plant is also called estafiata, Artic sage, and mountain wormwood, and in Canada it is called pasture sagebrush. The name fringed sagewort or fringed sagebrush, is appropriate since the leaves are very finely divided and rather downy. It is a perennial and is adapted widely to the arid and semi-arid plains and mountains of the western United States.

Stems are from 4 to 24 inches in height, the composite flower heads are globe shaped and borne on a rather straight, slender stem, which is woody at the base and of ten much branched there. The stems are erect, rather leafy and densely haired. The plant has a "sagey" fragrance.

Fringed sagewort increases in grasslands grazed by cattle to a point where production of palatable forage is substantially reduced.

Chemicals, Rates, Volume and Carriers

Experimencal work on control of fringed sagewort has been very limited. What little information is available is not of a quantitative nature. Incidental to loco control, applications in Montana where 2, 4-D was applied in water and in oil at the rates of 1 to 3 pounds per acre, substantial reductions in the stand of fringed sagewort were noted. These applications were made during the early part of the growing season when white point 1000 was in the early growth stage. Also incidental to big sagebrush control operations, good control of fringed sagewort was obtained where aerial applications of 2 pounds per acre of 2,4-D in oil and water were applied from an airplane.

General Considerations

Fringed sagewort has been found to be palatable and nutritious to sheep on winter range in Montana. On such range and possibly in other instances, it might be a desirable plant and control would not be indicated.

\section{$\underline{\text { References }}$}

Range Plant Handbook, USDA Forest Service, 1937. p. 323.

Payne, G. F., and F. A. Branson, 1956. Personal conferences, Montana Agr. Sxpt. Sta. Bozeman, Montana. 


\section{BITTERNEED (Hymenoxys odorata DC.)}

\section{Species, Description and Distribution}

Bitterweed is a member of the composite family. It is an annual, usually much-branched plant, that varies in height from a few inches to about 2 feet according to environmental conditions. Each of the ascending stem branches terminates in a yellow-flowered head. The flower heads are made up of many small flowers, and under normal growth conditions each head produces from 25 to 75 seeds. Seedlings or older green plants may be found at almost any time of the year in certain localities, but most growth is from early spring to early or midsummer. If climatic conditions are favorable, growth may start as early as December. The plant has a bitter taste and the leaves give off an aromatic odor when crushed.

This species (Hymenoxys odorata) is related to Pingue (Hymenoxys richardsonii Hook.) another poisonous plant of the same genus which causes heavy death loss of sheep on ranges of Colorado, Arizona and New Mexico.

Bitterweed is widely distributed in Texas and extends to California and from Kansas south into Mexico. It occurs on overgrazed or disturbed range $l$ ands.

\section{Chemical Control}

Herbicidal control has been practiced with varying degrees of success. The best kills to date have been obtained with the esters of $2,4-D$. Water solutions at concentrations of 0.2 percent applied as wetting sprays or a spray of 1 pound of acid equivalent of 2,4-D. in 25 to 50 gallons of water per acre applied with power equipment has given good kills.

\section{Time of Application}

Spray before flowering period. Mature bitterweed plants and those growing on dry habitats are difficult to kill with herbicides.

\section{General Considerations}

Animals poisoned: In general sheep are readily poisoned by eating large amounts of bitterweed, and even cattle losses have occurred in certain heavily infested areas. Sheep poisoning by bitterweed has been very common in the Fdwards Plateau region of Texas in the winter and early spring before green forage was available.

Poisonous nature and symptoms: From studies made in Texas it is apparent that bitterweed is more toxic during drouth years than under conditions approaching normal rainfall. It has been determined that about one pound of green immature bitterweed will kill sheep if eaten during a period of two days. 
The most common symptoms of bitterweed poisoning are loss of appetite, cessation of rummation, depression, indications of abdominal pain, bloating, and green regurgitated material about the mouth and nose. Post-mortem observations will show congestions of the lungs as well as other internal disturbances.

Control and management: There is no medical cure for severely poisoned animals therefore, as soon as animals show symptoms of poisoning they should be renoved to clean or desirable pastures or put on feed. Good condition range is the answer to controlling bitterweed.

\section{References}

Boughton, I. Bo and W。 T. Hardy, Toxicity of Bitterweed for Sheep. Texas Agri。 Expt。Sta。Bul。 553. Aug. 1937.

Hardy, W. T., V. I. Cory, H. Schmidt, and T. H. Dameron. Bitterweed Poisoning in Sheep. Texas Agri. Expt. Sta. Bul. 433. August 1931.

Sperry, Omer E., J.W. Dollahite, Judd Morrow and G. O. Hoffman. Texas Range Plants Poisonous to Livestock. Texas Agri. Expt. Sta. Bul. 796.

Vernon A. Young 


\section{PRICKLY PEAR (Opuntia platyopuntia)}

\section{Description and Occurrence}

Several species of prickly pear are associated with the title Opuntia Platyopuntia. The name Platyopuntia refers to the flat jointed species which are adapted to rather large grassland areas of the central and southern Great Plains of the United States. They vary in size from the rather low growing plants of central plains areas to huge plants common to given areas of south Texas. The two principle methods of controlling or eradicating prickly pear that grows on range lands are by grubbing and the application of chemical treatments.

\section{Chemical Methods of Control}

Chemicals normally used for control of prickly pear include the $2,4,5-T$ esters, mixtures of 2,4-D and 2,4,5-T esters, silvex, sodium trichloroacetate. (TCA), and dinitro compounds in diesel oil on kerosene or emulsions containing various ratios of water and oil. These chemicals may be used effectively for control of all forms of most prickly pear plants provided all the parts are thoroughly covered.

The chemical 2, 4,5-T is commionly used in the treatment of Opuntia platyopuntia species in the Southwest and certain adjacent areas. Since the sale of this hormone-type herbicide is regulated by the law in certain states one should become familiar with the requirements relative to where and how it may be used.

\section{Rates, Volume and Carrier}

$2,4,5,-T$ solutions are usually explained in a descriptive writeup attached to the container in which it is sold. A one percent solution of 2,4,5-T has been most effective for controlling Engelmann and Nopal prickly pear in the Southwest. However, stronger solutions may be necessary in certain other locations.

Hand application of 2,4,5-T solutions with knapsack, compression tank-type and power sprayers have been most effective for prickly pear control. Pressures of 25 to 35 pounds for hand sprayers and 40 pounds for power sprayers are recommended. Large-size droplets are more desirable for covering prickly pear plants than small size or fog-like droplets. Both sides of the prickly pear pads, joints and fibrous trunks must be wet thoroughly to the point of slight runoff to obtain effective kill and control. Diesel oil or kerosene should be used with hand sprayers, while oil-water emulsion can be used in power sprayers equipped with agitators. Emulsion sprays are as effective as oil sprays if kept agitated but more volume of solution is required for treating individual plants. Use of emulsion will reduce the cost of treating prickly pear on large areas. Boom-type sprayers have not been as satisfactory in spraying the prickly pear plants in regions as those methods cited above. 


\section{Time of Appication}

Dwing the ho' sumer month is nevally the most desimable period ron spraying the species Opuntia P o cintia.

\section{General ounsiderations}

Grubbing and pilting of pricily pear is practical on many range lands and is nevi?g done on a contract basis for th. Co to $\$ 9.50$ per ajre derending on tille sposites and the density of the plants. The piles are ofter bumeri during the clack work season on many ranches.

Gcod cange manament practices are the key to prevent reinfestation of prichy pera areated ranges. otherwise the above creat-

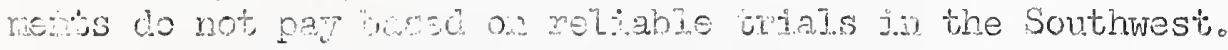

\section{Refererces}

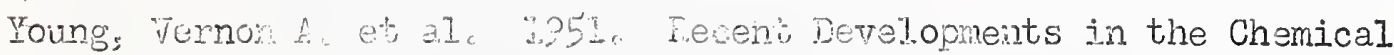
Contro? or Prugh un Teres Ranges. Bull, 723, Tex, Agri. Expt. Bul.

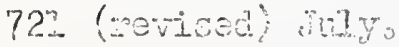

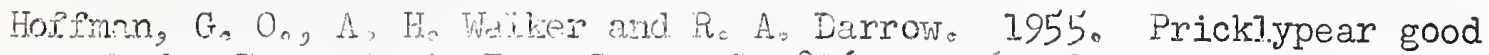

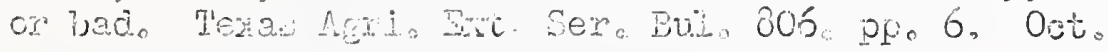

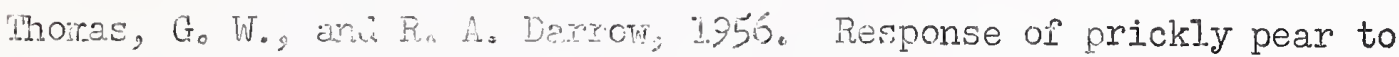
grazing and control nessues, Feras Range Station, Barnhart. Tex Agri, Furot. Star Frog, Font, 23:3, po. ?.

Vernorn A。 Foung 


\author{
POST OAK (Quercus stellata Wangenh.) \\ BLACKJACK OAK (Quercus marilandica Muenchh.) \\ Description and Occurrence
}

These two oaks are coimonly associated with each other. Post oak is distributed Irom Cape Cod west through Central Ohio, south to Iowa, south to Central Texas and Northem Florida. Blackjack oak is quite widely distributed and occurs rather abundantly in certain areas of the following states: New York, New Jersey, Pennsylvania, Ohio, Michigan, Illinois, Iova, Nebraska, Oklahoma, Texas and Florida.

The above two oaks have litile to no grazing or commercial value. They form dense stanc:s on areas thet, have been heavily grazed or where desirable hardwoods have been removed. This is especially true in Texas where these undesirable woody species have increased in numbers on approximately 18 milicn 2 of range lands. These oaks have a relatively high water recuirement and compete effectively with forage species for soil moistuie.

\title{
Nobods of Control
}

Mechanicel - Such methods as bulldozers, anchor chains and girdling on large trees have given varions cegrees of success. Brush and weed cutters as well as root plows have been quite useful in the control of oak saplings. However, under such treatments some provision should be made for the grazing of goats to controi the sprouts which arise following such treatmentis.

Chenical . These oaks can be controlled with one or two aerial applications of 2, $4,5-m$ or Silvex $(2,4,5$. Trichloropropionic acid) esters. Recommended ireatments are one and one-hali pounds of 2,4,5-T or one and one-foum pounos Sivox per acre (acid equivalent basis) initially followed by an additional one pound of 2,4,5-T or three-fourths pound. of Silvex during the first or secoild subsequeint growing season. Aerial applications are mads as 1.3 oil/trater emulsions at a volume of four gallons per acre. Bjack cak is less susceptible than post oak to these chemicals, and $2,4,5,5$ shou?d be used when boin oak or other weed trees species are preserit.

Post and blackjacl oak can anso be controlled using individual plant treatments by spraying the foliage, the stem from ground level up 12 to 14 inches or by infecting the killing solution into the plant directly or inito the soij at the base of the tree. Foliage sprays containing 2 to $3 \mathrm{ahg}$ (acio equivalent per 100 gallons) of 2,4,5-T or Silver should be applied tio the point of runoff. Spraying the trunk base with a solutioil of 12 to is pourds ang of 2, 4, 5-T in diesel oil is effective on trees with stems not greater than five or six inches in diameter? Silrex should not be sprayed on the trunk base. 
Various herbicides such as 2,4,5-T, Silvex and Ammate (ammonium sulfamate) may be injected directly into the plant by utilizing freshlycut surfaces such as frills or stumps near the ground. Frills consist of a band of overlapping downward ax cuts completely circling the trunk. Better kills are obtained from frills and stumps cut near the ground level. Particular attention should be paid to treating the cambium and outer bark surface of stumps.: Oil solutions containing 12 to 16 ahg of 2,4,5-T or Silvex are effective; ammate can be applied as crystals or in water solutions containing not less than three pounds of ammate per gallon.

Injection of oil solutions containing 8 ahg of $2,4,5-T$ into the soil at the base of trees less than six to eight inches in diameter is an effective treatment. An inexpensive soil fumigating gun is used for making the treatmen's.

\section{Time of Application}

Foliage sprays are restricted to the period of active growth after the leaves become full-iice. Trunk base sprays are most effective if applied during the winter. dormant period. They can be used during summer, but are ineffective during the initiation of growth in the spring or other seasons. Cut-surface treatments are used generally over the entire year. Soil injections should be made only during early spring and during the period of maximum plant activity.

Experimentally, substituted ureas appear to offer considerable promise as trunk base spiays or broadcast in granular form over the soil surface. Elackjack and post oaks are equally susceptible, but some other associated woody plants are not so sensitive.

Before any of these ireatments are applied more complete information should be obtained from publications listed below or other informed sources.

\section{References}

McCully, Wayne Go 1955. Soil Injection of Herbicides for Controlling Individual Brush Plants, Texas. Agri。 Expt, Sta. Prog. Rept. 1869.

Walker, A. H. 1955. More Grass From Controlling Trees and Brush With Chemicals, Teras Agric。 Ext. Serv。 Bull.800。

Young, Vernon A., C. E. Fisher, R. A. Darrow, W. G. McCully and D. W. Young. 1951. Recent Developments in the Chemical Control of Brush on Texas Ranges. Teras Agri。 Expt。Sta. Bull. 721, Revised July 1951.

1952. Desirable Grasses Increase After Post Oak Control. Texas Agri. Frupte Sta. Prog. Rept. 1448. 


\section{SAW PALAETTO (Serenoa repeñs /Bart7 Small)}

\section{Description and Occurrence}

Saw palmetto, the commonest of our native palms (1), occurs from the Florida Keys to Louisiana and South Carolina. The robust stems of this large evergreen shrub characteristically are horizontal and creep just under or at the surface of the ground. If not kept down by burning short erect trunks may form; these may branch and become a tree up to 25 feet tall. In the acaulescent form stems branch frequently. They form a tangled mass with the leaf crowns arising above them to form an almost inpenetrable thicket. Palmetto's immense colonial aggregation frequently covers large acreages with thousands of individual specimens living in close proximity.

\section{Chemicals}

Nation ( 3 and 4) reports good kill with isopropyl ester and polypropylene glycol butyl ether ester of 2,4,5-T. Sodium trichloroacetate (T.C.A.) also gave good results. When used alone, 2, 4-D was ineffective but could be used to replace some of the 2, 4,5-T in a mixture.

Cassady (2) indicates individual plants may be killed by injecting ammate (ammonium sulfamate) into the bud or stems and following with a spray of the same chemical on the bud and new growth.

In screening tests at Olustee, Florida (5) spray applications of the following chemicals were ineffective: ammonium sulfamate, ammonium thiocyanate, methyl ester of 2,4-D, pentachlorophenol, and kerosene.

\section{Rate, Volume and Carrier}

Most effective rates reported by Nation ( 3 and 4 ) were 5 to 6 pounds acid equivalent of polypropyle ne glycol butyl ether ester or isopropyl ester per 100 gallons of water, or the same amount as a mixture of equal parts 2,4,5-T and 2, $4-D$. Oil apparently increases the effectiveness of these chemicals. With 10 gallons of oil in 90 gallons of water three pounds acid equivalent of 2,4,5-T appear sufficient.

Rate trials for T.C.A. are limited but $\frac{1}{2}$ pound to 1 gallon of water is recommended.

For all the above chemicals it is important to spray foliage until thoroughly wet. No set figure can be given but 100 to 150 gallons of solution per acre is suggested.

With ammate, inject 1 to 4 tablespoonfuls into growing and conducting tissue; spray new growth with 32.5 percent ammate solution ( 4 lbs. added to 1 gal. of water).

\section{Time of Application}

If palmetto is cut off; spraying should be delayed until sprouts are six months old or until a majority of potential buds have sprouted. 
Best time of spraying is not known. Most effective treatments in Florida were from October to December. June applications were nearly as effective but results in March were poor. Good kills have been obtained from August sprayings in Georgia.

Ammate is probably least effective in spring.

General Considerations

Chemical effects can not be assessed until 1 or 2 years after application. Results are faster and more conclusive when chemicals are used in open areas.

Mechanical measures are widely used on relatively high value land. This is too expensive and impractical for eradication and control where land use is mainly for grazing and timber production. Chemicals appear promising but expense still restricts their use. More efficient and economical measures are sorely needed.

Abundance of this palm has long constituted a challenge for someone to make profitable use of the leaves and trunk. Leaves have been manufactured into paper of poor quality. Trunks have been processed to serve as a cork substitute for floats and gun plugs. The conducting bundles in stems represent a potential source of fibers.

\section{References}

1. Bombard, Niriam I. 1950. Palm trees in the United States. USDA Information Bulletin 22, 26p.

2. Gassady, John S. 1948. File correspondence on plant control. Southerin Forest ixp̄t. Stà., Alexandria, La.

3. Nation, H. A. 1950. Two chemicals appear promising for control of palmetto, Proc. Thira Annual Southern Weed Conference.

4. 1951. Palmetto can be controlled with chemicals. Proc. Fourth Amnua. I Southern Weed Conference.

5. Perry, John $H_{0}$ 1948. Palmetto poisoning. Office report. Southeastern Forest Expt。Sta. Lake City, Florida.

Lowell K. Halls 


\section{GALLBERRY (Ilex glabra [L.7 Gray) \\ Description and Occurrence}

Gallberry, a member of the holly family, is a common evergreen shrub, usually 2.5 feet tall that occurs abundantly in low pinelands, swamps, and prairies of the Southeastern Coastal Plain region. It spreads both by seed and rhizones. This plant is worthless for browsing, acts as a physical barrier to good forest land management, increases the hazard and intensity of fores' fires, and competes unfavorably with desirable forage plants and tree reproduction.

\section{Chemicals}

$\mathrm{Halls}$ and Burton (I) report kills of 90 percent from spray applications of $2,4,5 \%$ (isopropyl ester) singly and in a combination with (isopropyl ester) 2,4, 3 . The latter was not effective by itself. Fair results ( $50 \%$ kill) were obtained with sodium trichloroacetate (T.C.A.). Preliminary tests with $2,4,5$ - T in the amine form appear promising (2).

$$
\text { Rate, Volume, and Carrier }
$$

Most effective treatments have been 3.34 pounds acid equivalent of iscpropyl ester of $2,4,5 \mathrm{~m}$ per $100 \mathrm{gal}$. of water or a combination of 2.5 pounds $2,4,5-\mathrm{T}$ and 2.5 pounds acid equivalent of 2,4-D per 100 gallons of water, at rate of 175 gal. per acre.

Oil as a carrier has not been sufficiently tested to warrant any conclusions. Iikewise, a study relating rates and season of application for $2,4,5-\mathrm{T}$ is still in the preliminary stage.

T. $\mathrm{C}_{n} A_{\text {c }}$ has been tested at one rate only, 12 pounds per 20 gal. of water, 775 gal. per acre。

\section{Time of Application}

All reported applications have been made during rapid growth period in spring (March). Other seasonel effects are under investigation.

\section{General Considerations}

Jongtime residents of south Georgia and north Florida frequently comment on the apparen' increase of this plant. With greater emphasis on timber and grazing land management practical metiods of gallberry eradication and conirol take on added importance.

Periodic burning of critical areas is the control method generally employed by landowners. This has a temporary effect of eliminating topgrowih. Resprouting following the burn is profuse and stems may actually become more numerous. Burning of gallberry six weeks to two months prior to spraying does not increase effectiveness of chemical. 


\section{References}

1. Halls, I. K. and G. W. Burton, 1951. Effect of 2, 4-D, 2.4,5-T and sodium trichloroacetate on gallberry. Jour. For. 49 (12): 895-897.

2. Hughes, R. H., 1956. Effect of chemicals and burning on gallberry. Field report. Tifton, Ga.

Lowell K. Halls 
WESTERN FAISE-HELIEEOPE (Veratrum califo micum Durand)

Western false-hellebore occurs on mountain meadows of the 11 western states. Low palatability and competition with more valuable forage plants for grazing on soils otherwise potentially high in production makes this plant undesirable on rangeland. Also, it contains a poisonous property but livestock are seldom poisoned under normal grazing conditions. The plants are strong perennials, 3 to 8 feet in height with a short, thick rootstock.

\section{Chemicals}

The ester form of $2,4-D$ has been effective in controlling western false-hellebore $(1,2)$. Diesel oil has also been used as a contact herbicide to eradicate this weed (3).

\section{Rate of Application, Volume and Carrier}

Butoxyethanol ester of $2,4-D$ at 2.6 pounds acid equivalent in 160 gallons of water per acre gave 93 percent kill of plants in California (1). A test using 4 pounds acid equivalent of isopropyl ester of $2,4-D$ per acre and retreatment at same rate one year later gave excellent control in Washington. The density of false-hellebore was only 6 percent of the density before spraying (2). Both the se tests may be considered preliminary with respect to development of recommendations to be prescribed for general use. The results are encouraging but more experimental work should be carried out with chemicals on this meadow weed.

Diesel oil having a specific gravity of 27 satisfactorily controlled westerm false-hellebore as an individual plant treatment (3). A regular oil can or a pressure sprayer of the back-pack type with nozzle removed to give a small stream was used to pour the diesel oil into the funnel like collars of the leaves. One gallon of diesel treated about 320 plants. Approximately 1000 plants were treated per man-hour.

Time of Application

Spray should be applied after most of leaves are expanded but before bloom appears. In Califormia this stage occurs about mid-June. The diesel oil treatment was most satisfactory when applied at the time the plants began to bloom. Earlier application was not as successful because young plants were too small and difficult to find.

\section{References}

1. Cornelius, Donald R. Annual Report, California Forest and Range Experiment Station, Berkeley, Calif., 1953: 1-64.

2. Rumme1I, Robert $S$. and Holscher, Clark E., Seeding Summer Ranges in Eastern Oregon and Jashington. U. S. Dept. of Agric. Bul. 2091: 1-34. 1955 . 
3. Stevenson, Ray. Preliminary Report on Eradication of Skunk Cabbage (Ve ratrum californicum)

Mimeographed pamphlet, U. S. Forest Service, San Francisco, California 1942: 1-12

\author{
Donald R. Comelius
}




\section{RUSSIAN KNAPNEED (Centaurea repens L.)}

Russian knapweed was introduced from the Caspian region of southern Russia into the United States with Turkestan alfalfa seed. "It now. occurs as a serious pest in Turkestan, South Africa, Australia, and the United States.

The creeping perennial rootstocks often extend to a depth of 2 to 4 feet. Plants are bitter and unpalatable to livestock.

\section{Chemicals for Control}

The amine form of 2,4-D is most general ly recommended for use in spraying. Soil sterilants that have proved to be effective are sodium chlorate, Poly-Bor chlorate, and Chlorax.

$$
\text { Rate of Application, Volume, and Carrier }
$$

Two applications per year of 2,4-D amine form at rate of 6 pounds per acre per spray treatment will control 90 percent of the original stand after one year (2). Early spring application of 40 to 80 pounds of 2,4-D amine form per acre with spot treatment of any regrowth will also control this weed (2).

Soil sterilants have been used on east side of Fresno county where soil is light textured and rainfall is from 12 to 16 inches annually with results from 95 to 98 percent effective (3). Rates of application per 100 square feet for different chemicals are as follows: sodium chlorate, 1 1/2 pound; Poly-Bor chlorate, 3 pounds; and chlorax liquid, $3 / 5$ gallon. Two treatments, each at these rates, are required. In west side of Fresno county the soil is heavy textured and rainfall from 4 to 7 inches each season. This rainfall is not enough to cause sufficient penetration of the sterilizing agents into the heavy soil. Here the successful treatment recommended is 10 pounds sodium chlorate per square rod followed by flooding with 10 to 12 inches of water. Roadside treatment recommended is 6 pounds Poly-Bor chlorate or $11 / 5$ gallons chlorax liquid to each 100 square feet (3). These borate compounds are safe from fire but sodium chlorate is a fire hazard.

\section{Time of Application}

Spraying with 2,4-D should be done just before bud formation (mid-June) and the second application made to standing injured weeds and regrowth, about 60 days later (2). Soil sterilants are applied in Fresno county, Calif.: first tréatment in December and second treatment in February (3).

\section{General Considerations}

Great care should be taken in obtaining clean seed for range reseeding projects. Fussian knapweed seed is especially well adapted for spread through alfalfa seed. It occurs in about 1 percent of all non-certified alfalfa seed samples analyzed by the ryoming State Seed Laboratory (). 


\section{References}

1. Bohmont, D.W. Weeds of Wyoming

Wyo. Agr. Expt. Sta. B. 325: 160 p. JuIy 1953

2. Weed Control in Wyoming Wyo. Agr. Expt. Sta. C. 59: 11 p. Apr. 1955

3. Polson, J. I. Soil sterilizing materials as used on Russian knapweed (Centaurea repens) in Fresno County. Calif. Weed Conf. Proc. 6: 49-51. 1954

Donald R. Cornelius 


\section{CANADA THISTLE (Cirsium arvense Scop.)}

Description and Distribution

Canada thistle was introduced into the United States and Canada during the time of the Revolutionary. War. This perennial weed is widespread throughout northern United States extending south to California and Virginia. Although considered of primary importance on cereal grain land it now occurs on all kinds of farming and grazing land and into forest areas. Reproduction is by creeping rootstocks and seed. Stems are 1 to 4 feet high, erect, rigid, and slightly pubescent. Plants are dioecious, that is, two types of flowers are produced: female (pistillate) and male (staminate). Usually the flowers on one plant are all of one type.

\section{Chemicals for Control}

Although somewhat resistant to 2, 4-D canada thistle has been successfully controlled by repeated treatment with this selective herbicide. Amizol (3 - amino 1,2,4 - triazole) tested in very recent years has given encouraging results.

\section{Rate of Application, Volume, and Carrier}

Two pounds, acid equivalent per acre, of the amine form of 2, 4-D is recommended per treatment. Over 90 percent of the original stand has been eliminated after three years' treatment (2). Water sufficient to give thorough coverage has been recommended as a carrier (4).

Heavy rates of $2,4-D$, from 40 to 80 pounds per acre, applied in early spring have given complete control of established stands of canada thistle (3).

The rate recommended for Amizol is 4 pounds in 20 or more gallons of water per acre.

\section{Time of Application}

First spray application is usually applied at pre-bud or early bud stage of development in late May or early June. Follow-up fall treatment should be one or two weeks before first frost, but can be treated later even after several light frosts (4). Clean cultivation from May through July with 2,4-D applied at rate of 2 pounds per acre about September 15 has given excellent results ( 5 ). After a period of clean tillage this fall spraying hits the plants while the leaves are young and succulent and carbohydrate translocation is at a relatively high level.

Amizol should be applied between the time most thistles have emerged and the bud-to-bloom stage. Treated plants should not be mowed but they may be plowed under 3 weeks after spraying (1). 


\section{General Considerations}

Canada thistle should be controlled by spot treatment when in early stage of invasion if possible. Considerable chomical and time will be required in treating and retreating if this perennial is allowed to spread over an extensive acreage. Abandoned crop land is most likely to be infested.

\section{References}

1. Beatty, R. $H_{6}$ Progress Report on 3 - amino 1,2,4-triazol (Amizol). Proc. 8th Annual Calif. Weed Conference and 15th Western Weed Control Conference p.61-63. Feb. 1956.

2. Bohmont, $D$, W. Weeds of Wyoming Wyo. Agr. Expt, Sta. B。 325: 160 p. July 1953.

3.

Wyo, Agr。 Ecpt. Sta。 C. 59: 11 p. April 1955.

4. Burns, V. F., Rasmussen, L. W., and Wolfe, A. H. Canada thistle (Cirsium arvense), white top (Cardaria) and morning glory (Convolvulus arvensis) control in orchards. Wash. State College Ext. Misc. Pub. 29. 4 p. Jan. 1955.

5. Rasmussen, I. W. Factors which determine the effectiveness of growth regulator herbicides on canada thistle (Cirsium arvense). West. Weed Control Conf. Proc. 13: 7-9. 1952.

Donald R. Cornelius 


\section{WIID IRIS (Iris missouriensis)}

Wild iris, Rocky Hountain iris, or western blue flag, is a native iris which grows in wet meadows and along streams from North Dakota to New Mexico and westward to the Pacific Coast from southern California to British Columbia (4). It is a perennial herb and appears to spread chiefly by rootstocks. Seed is abundantly produced, although data on germination are not available. Its pale blue to almost white flowers are borne on stalks 6 inches to 40 inches in height and are conspicaously visible in overgrazed pastures and ranges where soil moisture is high. It is worthless as a forage plant and constitutes a source of competition for moisture and nutrients with more desirable species.

\section{Chemicals}

Both the light and heavy esters of $2,4-D(1,2,3)$ have been found to be satisfactory for wild iris control, although Thornton found the heavy ester caused some injury to grass.

\section{Rate of Application, Volume and Carrier}

Two lbs. a.e. of an ester of 2,4-D per acre in either oil or water, or in an oil-water emulsion, at a volume of carrier adequate to secure satisfactory coverage is recommended. Volumes of 3 to $100 \mathrm{~g} \cdot \mathrm{p} . \mathrm{a}$. have been used with success.

\section{Time of Application}

Herbicide should be applied during the bud stage of development (2) or at early flowering (1) of wild iris.

\section{General Considerations}

In spite of the scarcity of published data on wild iris control, the effectiveness of the controls recominended above were quite definite. Thornton (3) tried other chemicals as well as that recommended, and although he found dalapon (2,2-dichloropropionic acid) to be effective, it was as harmful to grass as to wild iris. He also found 2, 4,5-T and a mixture of 2,4-D and 2, 4,5-T were less effective than 2, 4-D alone and also caused injury to grass.

\section{$\underline{\text { References }}$}

1. Burge, L. M. Personal communication.

2. Parker, Karl G. Personal communication.

3. Thornton, Bruce J. Wild iris or flag (Iris missouriensis) control with foliage applications of a light and heavy ester of 2, 4-D, a light ester of 2,4,5-T, a 50-50 combination of light esters of 2,4-D and 2, 4,5-T, and Dalapon. Res. Prog. Rpt. WWCC. 1956. 
4. U。 S. Forest Service, Range Plant Handbook. U. S. Dept. of Agriculiture. (Washington, D。C.) 1.937.

W。 Co Robocker 


\section{WILLOWS (Salix spp.)}

Probably no other Angiosperm is more conmonly associated with water than the willow. Several hundred species are found in the north temperate and subariic regions. They are generally distributed over the United States wherever there is an adequate supply of water to support their growth. Commercially, the willows are of little importance. They do have a place in prevention of stream bank erosion, however, and find some horticultural. use in parks and gardens. They are also utilized as browse for big game animals in winter range and are taken to some extent by domestic livestock. In the field of range and pasture management, willows encroach on hay meadows, and where water is in short supply, become a problem in water usage. Elsewhere, they are a brush problem and are often controlled in a general brush control program set up to kili other species at the same time.

\section{Chemicals}

An ester of 2,4-D has been found effective as a foliage spray for both aerial. and ground equipment $(1,2,4)$. For cut surface treatment, an amine salt of $2,4-D$ may be used (4), or a mixture of 2, 4-D and 2, 4,5-T (I) available as a commercial "brush killer." For basal treatment, brush killer is recommended (4).

\section{Rate of Application, Volume and Carrier}

Foliage spray: As a treatment for individual plants, 2 to 3 Ibs. of an ester of $2,4 \mathrm{mD}$ per 100 gallons of water or water plus $1 \%$ diesel oil applied in an amount to wet foliage has been found satiafactory. For aerial application, 2 to 4 Ibs. ester of 2, 4-D in 5 to 10 gallons of water or fuel oil is recommended. At the higher gallonage, water plus $21 / 2$ percent diesel oil has proven satisfactory.

Easal sprays: One lb. of brush killer in 6 gallons of diesel oil applied near the ground to the point of runoff should be used.

Cut surface: A "frill" or girdle, made with hatchet cuts around the base of the tree, should be filled with undiluted amine formulation of 2,4-D. Freshly cut stumps can be treated by painting or spraying to the point of runoff the cut bark and about 4 inches of the sapwood.

\section{Time of Application}

Foliage spray: Spring and surmer after leaves are fully expanded and soil moisture is not limiting. ferred.

Basal spray: Any time of the year, but winter and spring are pre-

Cut surface and stimps: Effective at all times, but best results are had from November through ITay。 
General Considerations

The reaction of willows to herbicidal treatment varies from species to species. Comparison of a compilation of results by Leonard (3) indicated that in most species where a 100\% topkill was obtained, there was rarely a 100\% root kill, and retreatment will most likely be necessary in an effective control program.

\section{References}

1. Derscheid, I. A. and E. K. Ferrell. Chemical control of woody plants. S. Dak. Agr. Expt. Sta. Cir. 114, 1955.

2. Herbicide Committee. Proc. 9th Meeting, Western Section National Weed Comittee (Canada). Part 2. 1956.

3. Leonard, 0. A. Classification of woody plant responses to herbicides. Res. Prog. Rpt., WWCC. 1954.

4. , and W. A. Harvey. Calif. Agr. Expt. Sta. Bul. 755. W. C. Robocker 
Fortail barley is an introducec perennial grass which now infests ail except the coutherm States prom the Nississippi River eastward. It ranges as far rowh as A? as'ra and south to Mexico. It is a coarse grass with a bunch habit of growth and grows from 6 to 24 inches in hejght. The heads consist of muerous one-seeded spikelets with two associated rudientany sphelets, all of which are awned. It is commonly found in bo wet spots of meadows and irrigated rields, on the ediges of ponds, streams and irrigation citches and in swampy, alkaline rlats. It begins grouth early in the spring and is often headed by the tine forage crope are pead ror trting. The large number of barbed aring wion can cause jujury and even deatín to Iivestock particularly

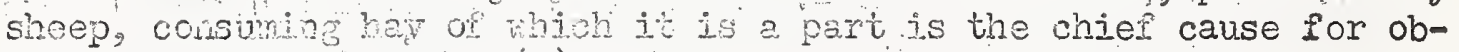
jection to its passiat (z).

\section{Chemicals}

In a series of toris by Corcis (i) IPC (isopiopyl phenyl carbamate), CIPC (isopropy $N$ (juchicrophenyl) carbamate), TCA (trichloroacetic acid, sodiun salt) stowed no promice for controlling foxtail barley. The scdium walt of dalepor (2,2 cichoropropionic acid) appeared to be the onty effectiv chemical of those tried in killing foxtail barley.

$$
\text { Pate ce Apojuctor, Voiume, and Carrier }
$$

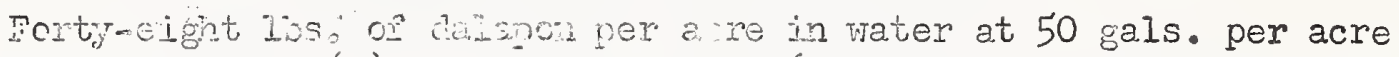
gate compete milis (ijo Juvez attes of 16 and 32 Ibso per acre allowed some survivei. A cuntinaticn cf 10 IUs。 of dalapon and 4 lbs. amino

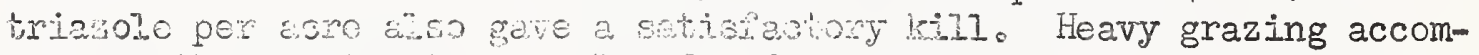

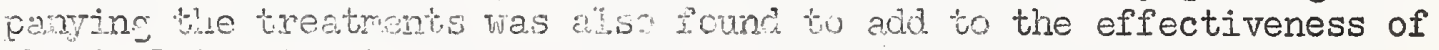
humical treatnomt.

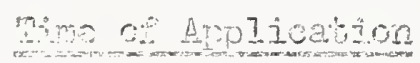

"pplications mere neje in bodr vay and Julyo Complete kills were

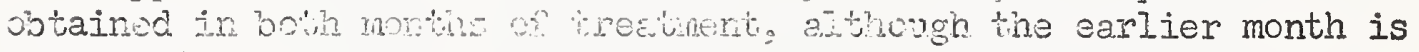

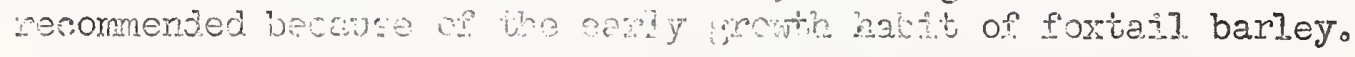

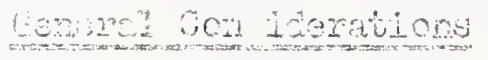

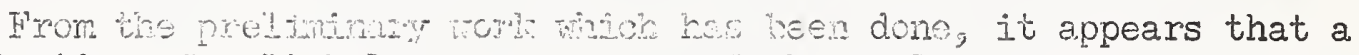
conbination of cuibunt. mangenpu, anc chenicai treatments may ulti-

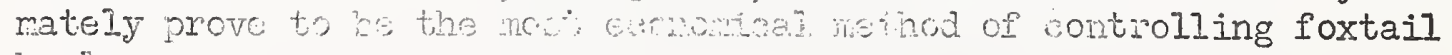
barieyn

\section{Dejerenes}

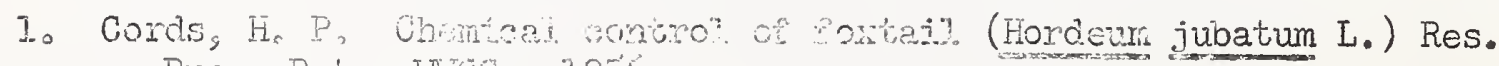
Progo Rpto, Thisge 2956.

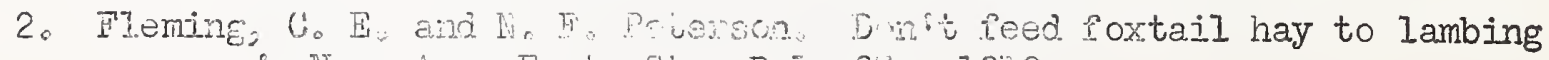

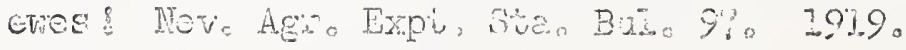




\section{GREASEWOOD (Sarcobatus vermiculatus)}

This is a spiny shrub which is common on alkali soils in many western states. It is a valuable fall and winter browse for livestock, provided it is eaten with other forage in ordinary amounts. The oxalate in young stems and fresh leaves has caused poisoning in sheep. Often there are but few other forage species in association with greasewood which might increase and offer incentive for greasewood control. The value to be gained on other areas is apparently an empirical estimate regarding the response of giant wild rye, salt grass, or other forage species. It seems advisable to proceed with greasewood control only on a demonstrational basis.

\section{Chemicals}

No data is available for citation, although considerable confidence has been expressed in the use of 2,4-D. Bohmont offered a positive recommendation, and Stoddart observed that greasewood is very highly susceptible to crown kills.

\section{Rate of Application, Volume, and Carrier}

Bohmont advised that 2, 4-D esters or amine at 1 to 2 pounds per acre has given 100 percent kill of greasewood. Volume and carrier is not stated, but it may be presumed that with this high susceptibility any carrier might be used at volumes as low as 5 gallons per acre.

\section{References}

1. Bohmont, D. W. 1952. Chemical control of poisonous range plants. Wyoming Agri.c. Exp. Sta. Bulletin 313.

2. Stoddart, L.A. 1956. Private correspondence.

3. A. H. Holmgren, and C.W. Cook. 1949. Important Poisonous plants of Utah. Utah State Agric. Exp. Sta. Special Report No. 2. 
BRO ON SNAKETEED, RAATCHWEET, TURPENTINE WEED, YELLONT TOP (Gutierrezia sarothrae)

Broom snakeweed is a half-shrub with woody roots, crowns, and stem bases. The species name "sarothrae" refers to the dense, broomlike bunches of dry stems. It has ax abundance of yellow, showy flowers, and is sometimes confused with green rabbitbrush (Chrysothamnus viscidiflorus). Snakeweed is widely distibuted over the western States, mostly at elevations from 4,000 to 8,000 feet. It is an agressive plant which invades areas where the clims regetation has been depleted, and is frequently abundant on the piains and on desert ranges of the Intermountain Region.

Throughout most of its range this plant is considered worthless as forage. However, on the winter xanges in western Utah and eastern Nevada, it ranks as fair forage for sheep during the fall and spring. Heavy utilization of this plart bi tivestock probably results in sickness or death, buic the plant is frecuentis grazed by domestic animals without ill effects. It has been describeci as a secondary selenium absorber in wyoming (Beath, 1953)。

\section{Chemical and liechnoical Control}

Burning with a flame gur, grubbiitg, mowing, and spraying with a 15 percent solution of sodiun chicrate were successful methods in the Southwest as early as 1939 (Perker)。 More recent work has obtained good control with 2,4-D esters, amine, and sodium salt, and with 2,4,5-T esters. In Arizona, TCA and dinitro-o secondary butyl phenol at high rates also gave gond kills $(4)$.

\section{Rate of Application. Tolime, and Carrier}

Data is not very plenting, and 2.17 of it cited comes from the Southwest. McIlvain reccminonds ? pound of 2,4-D acid equivalent in an ester form applied in either 3 gallors of diesel oil or in an emulsion of 2 to 4 gallons of water and 1 gallon of oil per acre. It appeared that 2, 4-D amine and 2, 4-D sodium salt was equally as effective as 2,4-D ester, and might be used at the same rate if snakeweed alone was to be killed.

Thompson Chemicals Corporavior did not get good kills with 1 pound of 2,4-D butyl ester, but 2 pouso.s in an oil envision at a total volume of 5 gallons per acre was ver efpertire.

2,4,5-T ester appeared to ba more effective than 2,4 $\mathbb{D}$ ester, but its higher cost justified less enthusiasitic secomendation.

$$
\text { rime of Application }
$$

After full-leaf development, during the period of most rapid twig elongation, and prior to flowering. In areas and vears when soil moisture in the growing season is serions? 1 injtitgg, a more precise definition of timing might be necessery. This timing vecurs in May and/or 
June with possible extension into July in the northern states and provinces.

\section{General Considerations}

No doubt primary attention should be given to improvements in grazing management where this plant is invading. However, timely range improvement where snakeweed is already dense appears to be a different, but not entirely separate, problem. The grass release provided by snakeweed control was well demonstrated by Parker. He measured a one-year grass-density increase of 196 percent above the increase on untreated plots when all the snakeweed was removed by grubbing.

\section{References}

1. Beath, O. A., et al. 1953. Poisonous plants and livestock poisoning. Wyo. Agric. Exp. Sta. Bulletin 34.

2. McIlvain, E. H. 1950. Unpublished data on chemical control of turpentine weed--provided by private correspondence Dec., 1956.

3. Parker, K. W. 1939. The control of snakeweed in the Southwest. Southwest Forest and Range Exp. Sta. Research Note No. 76.

4. Southwestern Forest and Range Exp. Sta. 1949, 1950, 1951. Annual Reports.

5. Thompson Chemicals Corporation. 1952. Progress Report. Chemical spraying of juniper \& pinion pine on Bar-T ranch, Arizona.

6. U. S. Forest Service. 1937. Range Plant Handbook. U. S. Government Printing Office, Washington, D. C. 
$\because$
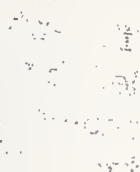